Crime and victimisation in the era of the United Nations Sustainable Development Goals

\title{
Robert Peacock
}

Department of Criminology, University of the Free State, PO Box 339, Bloemfontein 9300, Republic of South Africa

\begin{abstract}
Crime and victimisation have reached epidemic proportions. By fostering sustainable development within the social, economic and environmental spheres, the United Nations envisaged the strengthening of crime prevention and justice. However, within the global North/South divide there is little reason to assume that criminological and victimological interventions, development programmes or economic reforms can ever fully resolve the underlying causes of many victimological harms that affect developing or developed countries, unless and until they lead to greater freedom, equality and justice. Intersecting inequalities and social and economic exclusion highlight the importance of context and the complex geopolitical, institutional and ideological landscapes that gave rise to this global agenda. Together with the associated challenges for the successful implementation of the Sustainable Development Goals (SDGs), a critical appraisal of the nexus between crime, victimisation, justice and sustainable development on account of the gravest threat to humanity, namely climate change and environmental degradation, remains a functional imperative for research, policy and practice.
\end{abstract}

\section{Introduction}

It is only recently that crime prevention gained official recognition as a global sustainable priority by the international community. The United Nations' Millennium Development Goals (MDG) that preceded the 2030 Agenda for Sustainable Development (adopted in September 2015 by the United Nations (UN) General Assembly), did not consider crime and victimisation as important thematic components of the policy agenda but development on the other hand, has a longer history. Notwithstanding this oversight, the research of Blaustein et al (2018) shows that many development policies and practices are rooted in the colonial orientation that 'non-Europeans' or indigenous communities and colonial subjects were considered "backward," trapped in stifling cultural traditions. This moral devaluation of colonial subjects were fueled by the exploitation of natural resources and labour (the resource curse) that ultimately amplified inequalities between the colonisers and the colonies (as well as within the colonies themselves), and established long-lasting relations on the colonialpostcolonial continuum of economic dependency, reinforcing the 'underdeveloped' label.

This structural and institutional victimisation were accompanied by the importation of western legal systems with criminal justice as its agent (colonial policing and total institutions) by the colonial masters in order to subjugate and regulate the conduct of the colonized subjects whilst exploiting both their labour and land. 
The following discussion will focus on crime and victimisation within the context of the 2030 Agenda for Sustainable Development of the UN, but it is first necessary describe what is meant by sustainable development.

\section{Sustainable development}

From an extensive literature survey Du Plessis (2000) describes sustainable development as a dynamic and adapting balancing act between:

a) Using and protecting the physical and natural environment and its resources;

b) Creating equitable and viable economic systems with an ethical basis; and

c) Acknowledging and guiding social and cultural systems and values towards greater equitability, responsibility and human well-being:

Table 1. The Principles of Sustainable Development

\section{Environmental}

- Conserve the earth's vitality and diversity

- Conserve life support systems

- Use renewable resources sustainably

- Minimise use of non-renewable resources

- Minimise pollution and damage to the environment and health of all living creatures

- Conserve the cultural and historical environment

\section{Economical}

- Promote equity between nations and generations

- Avoid unequal exchange and ensure real-cost pricing

- Do not impoverish one group to enrich another

- Encourage ethical procurement and investment policies

- Promote equitable distribution of costs and benefits

- Support local economies

\section{Social}

- Allow improvement in the quality of human life

- Promote social equity amongst all peoples

- Allow for cultural and social integrity

- Foster self-reliance and self-determination

- Encourage participation and co-operation in decision-making on all levels from the individual to the international sphere

- Empower people and provide opportunity for capacity enhancement

However, researchers (Hove, 2004) consider the concept of sustainable development as both too broad and ambiguous with its multifarious policy choices, some of which are deemed contradictory and incoherent in efforts to be as encompassing as possible. A broad and varied approach presents furthermore with the risk of rhetoric and subsequent gaps in policy initiatives. Hove (2004) also highlights the ethnocentric Western conceptualisation of development where the so-called 'backwardness' and traditionalism of societies are viewed as barriers to progress. The policy of sustainable development fails furthermore to reconcile environmental protection and economic expansion and may simply serve to deflect the 
West's overconsumption and role in causing underdevelopment but also other global injustices by allowing for continued growth without real and meaningful reform. To be more meaningful reforms of sustainable development need therefore to account for the global North-South divide and subordination but also to focus on the immense concentration of power and wealth in the hands of a few in order to engage in a sustainable fashion with labour, production, global markets and other social relations that perpetuate inequality. Critical criminologists (Roth \& Kauzlarich, 2014) have demonstrated that these political elites uphold their privilege, status and interests by not only by defining crimes but also shaping criminal justice responses to it. The apartheid regime in South Africa serves as a good example. At the core of the massive violations of human rights lied the need for cheap and a readily supply of labour to ensure the continued exploitation of the country's great mineral wealth by the white elite (Peacock, 2011). As far back as the 1990s, the Colombian-American anthropologist Escobar (1995, p. 200) said “...it has become clear not only that capitalism impairs or destroys the social and environmental conditions on which it relies (including nature and labor) but also that capitalist restructuring increasingly takes place at the expense of those conditions."

If nothing other than a framework for research, Table 2 shows the Sustainable development goals adopted by the General Assembly of the UN (2015).

Table 2 Sustainable development goals

SDG 1. End poverty in all its forms everywhere

SDG 2. End hunger, achieve food security and improved nutrition and promote sustainable agriculture

SDG 3. Ensure healthy lives and promote well-being for all at all ages

SDG 4. Ensure inclusive and equitable quality education and promote lifelong learning opportunities for all

SDG 5. Achieve gender equality and empower all women and girls

SDG 6. Ensure availability and sustainable management of water and sanitation for all

SDG 7. Ensure access to affordable, reliable, sustainable and modern energy for all

SDG 8. Promote sustained, inclusive and sustainable economic growth, full and productive employment and decent work for all

SDG 9. Build resilient infrastructure, promote inclusive and sustainable industrialization and foster innovation

SDG 10. Reduce inequality within and among countries

SDG 11. Make cities and human settlements inclusive, safe, resilient and sustainable

SDG 12. Ensure sustainable consumption and production patterns

SDG 13. Take urgent action to combat climate change and its impacts

SDG 14. Conserve and sustainably use the oceans, seas and marine resources for sustainable development

SDG 15. Protect, restore and promote sustainable use of terrestrial ecosystems, sustainably manage forests, combat desertification, and halt and reverse land degradation and halt biodiversity loss

SDG 16. Promote peaceful and inclusive societies for sustainable development, provide access to justice for all and build effective, accountable and inclusive institutions at all levels

SDG 17. Strengthen the means of implementation and revitalize the global partnership for sustainable development 
(UN General Assembly Resolution 70/1)

All major world leaders are committed to achieve the seventeen Sustainable Development Goals (SDG) by 2030 in "Transforming Our World: The 2030 Agenda for Sustainable Development" (United Nations General Assembly 2015). There are over 150 targets, of which about 15 are concerned with reducing violent victimisation, including violence against women, traffic fatalities and violence in urban areas by 2030 . The targets of reducing the massive incidence of interpersonal violence are set out in SDG 3, 5, 11 and 16. These include targets in SDG 5 for the reduction of violence against women together with the reduction of all forms of violence and related deaths in SGD16.as well as equal access to justice for all.

Prior to the Corona virus pandemic, the implementation of the SGDs have been uneven across countries, goals and targets. In Africa the top performers were Mauritius, Botswana, Ghana and Rwanda, almost half of the remaining countries (18/46) in Sub-Saharan African were less than $50 \%$ on the way towards meeting the best possible outcome and were off-track on most SDGs (Brookings, 2020; Foresight Africa; 2020; Human Development Report, 2020).

Despite data gaps and timelines that are likely to undersestimate the decline in SGD performance globally, the global average of the SDG Index score for 2020 has decreased from 2019, a decline driven by increased poverty rates and unemployment following the outbreak of the COVID- 19 pandemic (Sustainable Development Goals Report, 2021).

With reference to the inequality of victimisation, at the 2020 Nelson Mandela Annual Lecture the UN Secretary-General António Guterres referred to inequality as an issue that defines our time, that risks destroying the world's economies and societies. Structural inequalities, environmental degradation, and the climate crisis and climate injustice as an impediment to peace - are all global risks that have been ignored for decades with the vulnerable and developing world or global South suffering the most but with consequences to all worldwide (Peacock, 2021).

\section{Peaceful and just societies}

The Global Peace Index (2021) demonstrates that since 2010, the number of conflicts globally has increased by 88 per cent. However, the full impact of the COVID-19 pandemic on peacefulness is still unfolding with growing unease with lockdowns and rising economic uncertainty resulting in civil unrest. It is still too early to fully assess the long-term effects of the pandemic on peace but the changing economic conditions in many nations increase the likelihood of political instability and violent demonstrations. Extensive data collection by the Armed Conflict Location and Event Data Project (ACLED) (2021) shows that a large portion of the globe is presently engulfed in some form of conflict (battles, violence against civilians, explosions/remote violence, riots, strategic developments).

With reference to the globalisation of crime and victimisation (and not referring here only to the global incidence of transnational organised crime) the World Health Organisation (2020) estimates that globally, up to 1 billion children aged 2-17 years, have experienced physical, sexual, or emotional violence or neglect in the past year (Target 16.2 of the 2030 Agenda for Sustainable Development reads to "end abuse, exploitation, trafficking and all forms of violence against, and torture of,children"). Lockdowns are also increasing the risk of violence against women and girls. Research shows that cases of domestic violence have increased by $30 \%$ in some countries, a phenomenon also more associated with low- and middle-income regions (Sustainable Development Goals Report, 2021). High homicide rates have been traditionally associated with the global South with countries such as El Salvador or Honduras that feature some of the highest homicide rates in the world (Blaustein et al 2018). The World Bank has shown the extent to which violence detracts from economic 
development with Low and Middle Income Countries (LMIC) in Latin America and the Caribbean forfeiting 5-15\% of their Gross Domestic Product to violence. Violence often causes the destabilization of young democracies and contributes to further victimisation when governments resort to military solutions and abuse of power in efforts to maintain the status quo (Waller, 2020).

Less visible than interpersonal violence is the prevalence of state-corporate crime with much more of a detrimental impact on reconstruction, the provision of basic services and the well-being of all than in the case of street crime (see Target 16.5 in the Table 3 below). According to the UN Convention Against Corruption (2004) it presents with a wide a range of corrosive effects contributing amongst others to human rights violations, organized crime, terrorism and threats to human security. Corruption occurs in all countries but it is in the global South where it is experienced as the most destructive.

Fighting corruption, reducing violence and improving access to justice are hardly controversial aspirations (see SDG 16 in Table 3), and together with the structural causes and crime and victimisation risk factors (Phillips, 2019, Siegel, 2018) that are cross-cutting under the SDG goals, it has been the foci of considerable criminological enquiry since the advent of modernism and urbanisation

Table 3 Goal 16: Promote just, peaceful and inclusive societies

1. Significantly reduce all forms of violence and related death rates everywhere

2. End abuse, exploitation, trafficking and all forms of violence against and torture of children

3. Promote the rule of law at the national and international levels and ensure equal access to justice for all

4. By 2030, significantly reduce illicit financial and arms flows, strengthen the recovery and return of stolen assets and combat all forms of organised crime

5. Substantially reduce corruption and bribery in all their forms

6. Develop effective, accountable and transparent institutions at all levels

7. Ensure responsive, inclusive, participatory and representative decision-making at all levels

8. Broaden and strengthen the participation of developing countries in the institutions of global governance

9. By 2030, provide legal identity for all, including birth registration

10. Ensure public access to information and protect fundamental freedoms, in accordance with national legislation and international agreements

11. Strengthen relevant national institutions, including through international co-operation, for building capacity at all levels, in particular in developing countries, to prevent violence and combat terrorism and crime

12. Promote and enforce non-discriminatory laws and policies for sustainable development

Source: Adapted from United Nations Sustainable Development Goals

https://www.un.org/sustainabledevelopment/peace-justice/

Target 16.3 (Table 3) needs to be read together amongst others with SDG 10 (Table 2: Reduce inequality within and among countries). But first what is meant by "Access to Justice?" On 29 November 1985, the General Assembly of the United Nations adopted the Declaration of Basic Principles of Justice for Victims of Crime and Abuse of Power (General Assembly resolution 40/34, annex) based on the conviction that victims should be treated with compassion and respect for their dignity and that they are entitled to prompt redress for the harm that they have suffered, through access to the criminal justice system, reparation and services to assist their recovery. The Declaration recommends measures to be taken on behalf 
of victims of crime at the international, regional and national levels to improve access to justice and fair treatment, restitution, compensation and assistance. It also outlines the main steps to be taken to prevent victimisation linked to abuse of power and to provide remedies for the victims.

Already in a pre-Covid world, Fattah (2010) maintained that internationally most victim programmes and services remain in essence low budget enterprises that rely considerably on volunteers and grassroot organisations, without much consideration for the real needs of the injured party(ies).

Compensation programmes are also difficult to access, with the burden of proof on the aggrieved party and eligibility primarily restricted to so-called "pure victims" or ideal or 'innocent victims to use Nils Christi's terminology. Given the small figures involved (in comparison to the vast amounts generally allocated to injuries due to accidents, or medical malpractice), it does not surprise that often these programmes are deliberately not advertised. Lengthy bureaucratic processes and investigations render them problematic and primarily a symbolic gesture to be both manipulated by political agendas and to appease society's conscience, rather than to alleviate the distress of interpersonal and broader societal conflict effectively (Peacock, 2019). It is usually those who are marginalised and demonised who suffer the greatest burden of victimisation, but these are also the ones who benefit least from the services and programmes made available to crime victims (Fattah, 2019; 2020).

Recent research in the more resourceful context of the global North by Marc Groenhuijsen (2019) on the EU Directive Establishing Minimum Standards on the Rights, Support and Protection of Victims of Crime (2012), shows victim support systems and access to justice fall short for all types of victims among the Member States.

Also, within the global South, which is marked by the 'resource curse' and the aftermath of colonisation and its associated structural and institutional violence, victimisation, continues to play out in multiple deprivations, recurrent indignities, elite politics, sociopolitical instability, state-corporate crime and corruption with little access to state resources and a meagre regard for so-called 'disposable' or marginalised victim groupings such as offenders as victims, street children, child soldiers etcetera (Peacock, 2019; 2020). Intersecting inequalities and social and economic exclusion highlight the importance of context. With context one can refer amongst to the historical, cultural, socio-economic and political contexts with due recognition to the very root causes of crime and victimisation, i.e colonisation. Howard et al (2018) is of the opinion that the SDGs are likely to leave people behind since the contextual and particular way in which marginalisation is perpetrated are neglected.

Applying a gendered lens to all the goals contained within the SDGs is essential and commendable to ensure that any progress made is done with the experiences of women in mind (UN Women 2018). Gender equality is a requisite for eliminating violence against women on structural level but also critical to the elimination of interpersonal violence against women. Regrettably, with reference to gender the SDGs adopted a heteronormative approach for the international community by failing to address also the high levels of violence and discrimination experienced by members of the LGBTI+ community worldwide. This includes state-sponsored homophobia and the persecution of sexual minorities in both the Global North and the Global South. To demonstrate, in Africa only, 34 countries (Human Dignity Trust, 2020) criminalise private, consensual sexual activity between adults of the same sex, and the death penalty is imposed for similar deeds in five countries. Also, on the colonial-postcolonial continuum, state hate crime has been imported and perpetrated in the majority of countries in the Commonwealth, most of them former British colonies (Peacock, 2020). 
There is little reason to assume then that criminological and victimological interventions, development programmes or economic reforms can ever fully resolve the underlying causes of many victimological harms that affect developing or developed countries, unless and until they lead to greater freedom, equality and justice.

It is furthermore also widely accepted today that increasing the power of the criminal justice system (Target 16.3: Rule of Law) can be counter-productive when it comes to addressing the underlying structural causes of crime, inequality and victimisation. There is also a rik that any proactive policing strategy may be used to disproportionately to target ethnic minorities and indigenous communities (Blaustein et al 2018). See for instance the research of Chris Cunneen (2001) and Harry Blagg (2008) on aboriginal victimisation in Australia, the international crime of apartheid in South Africa (Peacock, 2011) and recent criminal justice events in the USA - thereby resulting in human rights violations and impacting henceforth on the legitimacy of the police and criminal justice system - already a particular concern around the importation of alien Western institutions of social control into the global South (Peacock, 2019).

\section{Ecological justice}

Table 3 indicates overarching environmental concerns such as ensuring universal access to clean water and sanitation (SDG 6), ensure sustainable consumption and production patterns (SGD 12), sustaining oceans and marine resources (SDG 14) and protecting and preserving territorial ecosystems (SDG 15). In addition, three targets focus on biodiversity and species protection with each signifying a different form of wildlife crime:

- SDG 14.6.1 Progress by countries in the degree of implementation of international instruments aiming to combat illegal, unreported and unregulated fishing;

- $\quad$ SDG 15.7 Take urgent action to end poaching and trafficking of protected species of flora and fauna and address both demand and supply of illegal wildlife products; and

- $\quad$ SDG 15.C Enhance global support for efforts to combat poaching and trafficking of protected species, including by increasing the capacity of local communities to pursue sustainable livelihood opportunities (UN General Assembly Resolution 70/1).

The recent Sustainable Development Goals Report (2021) showed that only a third of 113 countries were on track to achieve their national target to integrate biodiversity into national planning, ocean acidification continues to threaten marine environments and ecosystem services and by the year 2030 water scarcity could displace 700 million people with the escalation of micro-level and trans-boundary conflicts (Joy et al, 2018).

One of the greatest inequalities in the world is reflected in the causes and consequences of climate change. It is the poor who are the least responsible for greenhouse gas emissions, who are suffering the most (Castro, 2004). Without urgent action to limit global warming and to increase adaptation efforts immediately, it could become impossible for the impoverished to secure their livelihoods, also impacting negatively on a wide range of SDGs.

The toxicity of the industrialised nations, and its environmental impact on the already ravaged colonized global South but now also with universal consequences, requires that climate injustice should remain high on the victimological agenda. Global environmental change (GEC) would require a victimological framework beyond the orthodoxy of criminal law architecture and legal definitions of human rights and displaced persons, together with a critical engagement with western discourse on trauma (Peacock, 2019). To demonstrate, 
Susethyo (2012) refers, for instance, to the principle of state sovereignty as one of the major obstacles to the provision of disaster relief, in the absence of bilateral or regional treaties.

Furthermore, rather than looking for structural and systemic solutions, the concept of 'resilience' or 'to bounce back' (appropriated from the field of engineering) has become a popular catchphrase used by governments, international finance organisations and the NGO sector with reference to the assumed capacity of individuals and communities to deal with the distress resulting from ecological, socio-economical and political disturbances (Cretney, 2014; Peacock, 2021). In other words, we may not 'we may not be able to fix it' or 'we may not be able to stop it', but we can celebrate the resilience of the communities that continue to get through it. But continuously asking indigenous and non-western communities to be resilient in the face of land grabs, state-corporate crime and 'ecocide', the futilities of transgenerational structural and institutional victimisation remains concealed and unabated.

Finally, with reference to SGD 17 (Strengthen the means of implementation and revitalize the global partnership for sustainable development), to remain mindful of the observations of Rafaei (2020) that demonstrate how research collaborations and partnerships between the global North and the global South are often perceived as scientific colonialism where researchers in the global South have a minor role in shaping the research agenda or contributing to findings that are of relevance to the objectives of the northern partner. It is therefore possible that North-South partnerships may simply become a label of a rhetorical modernisation and 'legitimisation' of action, while sustaining a postcolonial, hierarchical, academic order. In concert with the emancipatory call of Escobar's (1992:27) for 'alternatives to development' as opposed to 'alternative models of development, communities at local level require agency to define development and progress for themselves in order to insulate the discourse and practice of development from 'the political, economic and institutional regime of truth production that has defined the era of development' (Escobar 1992: 28).

\section{Conclusion}

Sustainable development is a contested Western concept that raises critical concerns about culpability, responsibility and accountability. Rather than attempting to 'psychologise away' social and economic inequality and environmental degradation, a framework of justice, reconciliation and reparation is required that locates crime and victimisation in the multifaceted historical, geopolitical and cultural context of the structural and institutional victimisation of colonisation that led in the first instance to the massive inequalities within and between nations. If not, the poverty to engage with the ongoing consequences of colonialism can be considered a reproduction of colonialism. A decolonising framework is therefore required to transcend the legacies of economic, environmental and social injustice. But necessitates also a broad recognition, acknowledgement and redress of the links between poverty and the current world economic order. Local, national, and regional role-players need to be viewed finally as the co-owners of victims' concerns in order to advance an emancipatory agenda of a people's oriented victimological discourse in adressing the power imbalances, harm and injustices of a compromised, exploited and desecrated natural environment.

\section{References}


1. Armed Conflict Location and Event Data Project (ACLED) (available from https://acleddata.com/\#/dashboard (2021).

2. H. Blagg. Crime, aboriginality and the decolonisation of justice. Sydney: Hawkins Press (2008).

3. Brookings, Brookings Report Reflects on Africa's SDG Progress, Top Priorities to 2030 https://sdg.iisd.org/news/brookings-report-reflects-on-africas-sdg-progresstop-priorities-to-2030/ (2020).

4. J. Blaustein, N. W. Pino, K. Fitz-Gibbon \& R. White. Criminology and the UN Sustainable Development Goals: The Need for Support and Critique. British Journal of Criminology, 58, 767-786 (2018).

5. C.J. Castro. Organization \& Environment, 17 (2). 195-225 (2004).

6. R. Cretney. Resilience for Whom? Emerging Critical Geographies of Socio-ecological Resilience. Geography Compass, 8/9: 627-640, 10.1111/gec3.12154 (2014).

7. C. Cunneen \& S. Row, Decolonising indigenous victimization. In D. Wilson, \& S. Ross (Eds). Crime, victims and policy: international contexts, local experiences. New York: Palgrave MacMillan (2015).

8. C. Du Plessis, The Links between Crime Prevention and Sustainable Development.' (In Lawrence, R. (ed.). Sustaining Human Settlement: a challenge for the new millennium). North Shields : Urban International Press (2000).

9. A.Escobar, 'Imagining a Post-Development Era? Critical Thought, Development and Social Movements', Social Text, 31(23): 20-56 (1992).

10. E.A.Fattah, The evolution of a young, promising discipline: sixty years of victimology: a retrospective and prospective look. (In Shohom, S.G, Knepper, P. \& Kett, M. (Eds), International handbook of victimology). Boca Raton: Taylor and Francis (2010).

11. E.A. Fattah, Victimology: a discipline in transition. Vancouver: Ezzat A. Fattah (2019).

12. E.A. Fattah, Criminology today: a critical assessment. Vancouver: Ezzat A. Fattah (2020).

13. Foresight Africa, Achieving the Sustainable Development Goals: The state of play and policy options (available from https://www.brookings.edu/research/strategiesto-deliver-on-the-sustainable-development-goals-in-africa/ (2021).

14. Global Peace Index (2021). (available from https://reliefweb.int/report/world/global-peace-index-2021 (2021).

15. M.S. Groenhuijsen, Recent past and immediate future challenges of victimology in a volatile environment (In R. Peacock (ed.), Victimology in Africa pp. 363-387). Pretoria: Van Schaik (2019).

16. Human Development Report, The next frontier: Human development and the Anthropocene (available from https://reliefweb.int/report/world/humandevelopment-report-2020-next-frontier-human-development-and-anthropocene (2020).

17. Human Dignity Trust, (available from https://www.humandignitytrust.org/ (2020).

18. H. Hove, Critiquing Sustainable Development: A Meaningful Way of Mediating the Development Impasse? Undercurrent, I, (1): 48-54 (2004).

19. J. Howard, E. López \& J. Shaw, Navigating the pathways from exclusion to accountability: From understanding intersecting inequalities to building accountable relationships. Institute of Development Studies: Brighton (2018).

20. R. Peacock, The South African Truth and Reconciliation Commission-Challenges to Reconciliation (in R. Lecther, A Bouwer, A Pemberton (Eds) Victimological 
approaches to international crimes with a specific focus on Africa. Antwerp: Intersentia (2011).

21. R. Peacock, (Ed). Victimology in Africa. Pretoria: Van Schaik (2019).

22. R. Peacock, Reconceptualising hate crime in a restorative framework. International Journal of Restorative Justice, 3(3): 458-460 (2020).

23. R.Peacock, Justice for victims of crime and abuse of power: Challenges for policy, practice and research in the global North-South divide. Paper presented at the 14th UN Congress on Crime Prevention and Criminal Justice. Kyoto: 7 - 12 March (2021).

24. A.R. Phillips, Youth in conflict with the law: An exploration of socio-criminogenic risk factors, Unpublished MA dissertation, University of the Free State (2019).

25. S.E. Refaei, Global Research Partnerships: Beyond the North-South Divide? A Literature Review. Local Engagement Refugee Research Network Paper No. 4. March (2020).

26. D. Roth \& D. Kauzlarich (Eds). Towards a Victimology of State Crime..Oxford: Routledge (2014).

27. L.J. Siegel, Criminology: Theories, Patterns and Typologies. Cengage Learning : Boston (2018).

28. H. Susetyo, Victimological perspectives on the rights and present status of disaster victims: Indonesian situation (In Morosawa, H., Dussich, J.J.P. \& Kirchhoff, G.F. (Eds), Victimology and human security: new horizons). Nijmegen: Wolf Legal (2012).

29. Sustainable Development Goals Report

https://unstats.un.org/sdgs/report/2021/The-Sustainable-Development-GoalsReport-2021.pdf (2021).

30. United Nations General Assembly. Resolution 40/34 on Basic Principles of Justice for Victims of Crime and Abuse of Power. Retrieved from https://www.un.org/documents/ga/res/40/a40r034.htm. (1985).

31. United Nations Convention Against Corruption https://www.unodc.org/documents/treaties/UNCAC/Publications/Convention/0850026_E.pdf (2004).

32. United Nations Millennium Development Goals (MDG) https://www.un.org/millenniumgoals/2015_MDG_Report/pdf/MDG\%202015\%20 rev\%20(July\%201).pdf (2015).

33. I..Waller, What Can We Achieve by 2030? Rights for Victims of Crime in the Era of Sustainable Development Goals. (in J. Joseph \& S. Jergenson (Eds). An International Perspective on Contemporary Developments in Victimology) Springer: Berlin (2020). 